\section{Transient crossed aphasia during focal right-hemisphere seizure}

A. Riecker, MD; C. Gerloff, MD; D. Wildgruber, $M D$, MA;

T. Nägele, $M D$; W. Grodd, $M D$; J. Dichgans, $M D$;

and H. Ackermann, MD, MA, Tübingen, Germany

In nearly all right- and left-handed individuals, language is bound to the left hemisphere. Acquired language disorders subse-
Neurolmages

quent to right-hemisphere brain lesions in right-handed subjects amount to 1 to $3 \%$ of aphasic syndromes only. ${ }^{1}$ We report the rare case of a 59-year-old right-handed woman with transient global aphasia as the sole manifestation of a focal seizure (figure 1) due to a tumor of the right temporal lobe. Language functions recovered completely after seizure termination. fMRI demonstrated exclusive hemodynamic activation within right perisylvian areas during speech production and perception (figure 2). After tumor resection histologic examination revealed an astrocytoma World Health Organization grade III and the patient underwent polychemotherapy.
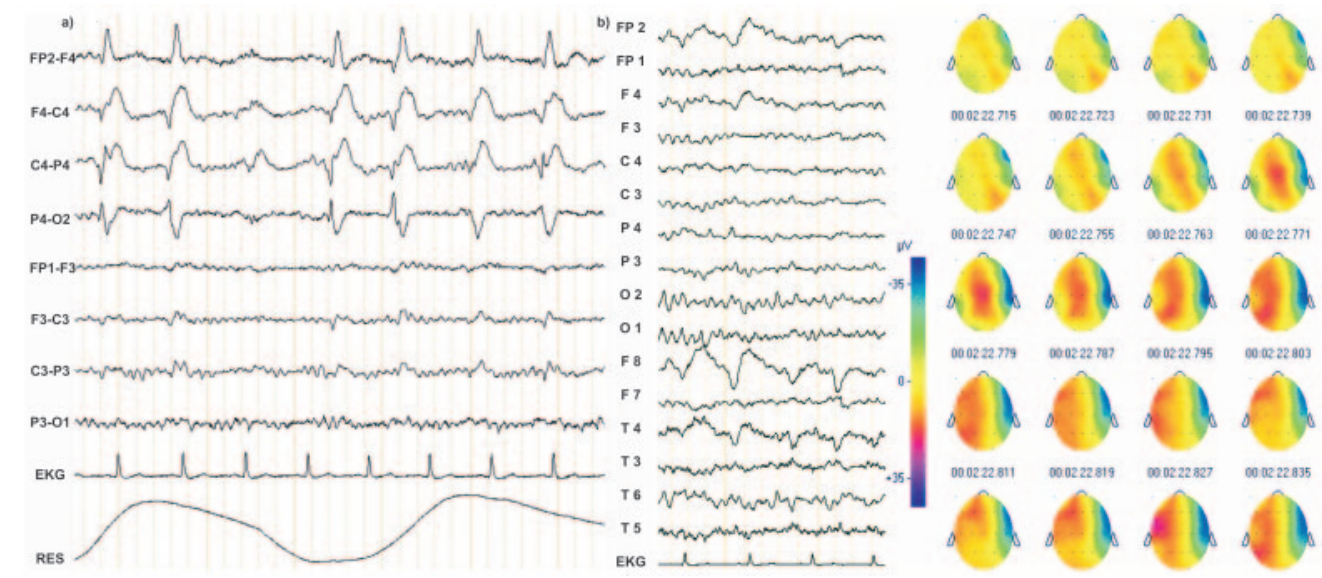

Figure 1. (A) Bipolar ictal EEG recordings (international 10/20 system) displayed right-hemispheric sharp waves extending across the entire seizure episode without propagation to the left side. (B) Source derivation after seizure termination shows a delta focus with a maximum at right-temporal leads (blue color-coding in topographic maps calculated at intervals of 8 msec).

a)

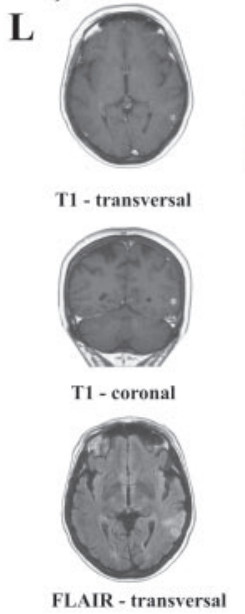

b)
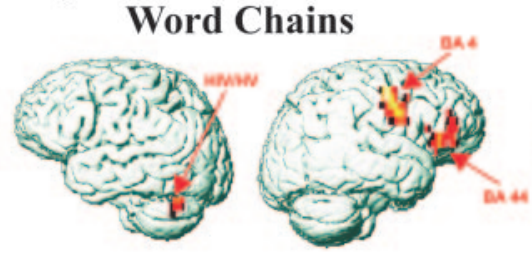

HIVAY :
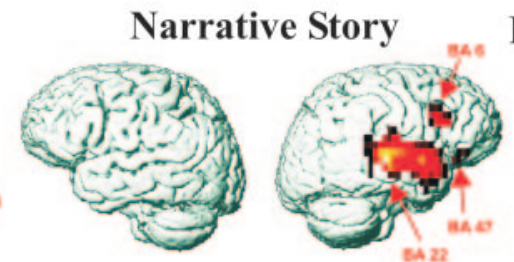

BA 22: $\quad x=54 \quad$ BA 6:

$\mathbf{L}$
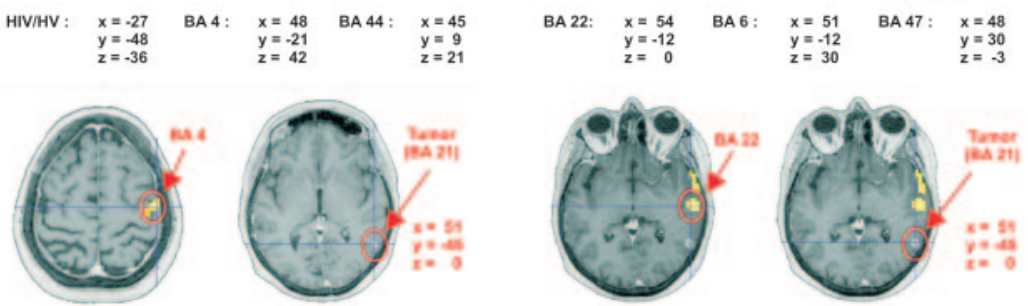

SPM $99, n=1, P<0.001, k>43, T>3.09$

Figure 2. (A) T1- and T2-weighted (fluid-attenuated inversion recovery) MRI displaying a central necrotic tumor (Ø 7mm) within the middle temporal gyrus surrounded by peritumoral edema. (B) fMRI activity during speech production (word chains) and perception (narrative story) superimposed on individual magnetization prepared rapid acquisition gradient recalled echo. ${ }^{2}$ The fMRI scans also display the distance between the tumor and the highest activated voxel during speech production and perception. Based on these data, it was expected that extended tumor biopsy should not yield any permanent aphasic deficits.

This study was supported by the Deutsche Forschungsgemeinschaft (SFB 307/10 and DFG-SPP). The authors thank Martin Staudt and Michael Erb for technical assistance and helpful comments.

Address correspondence and reprint requests to Dr. Axel Riecker, Department of General Neurology, Hertie Institute for Clinical Brain Research, University of Tübingen, Hoppe-Seyler-Strasse 3, D-72076 Tübingen, Germany, e-mail: axel.riecker@web.de
1. Alexander MP, Annett M. Crossed aphasia and related anomalies of cerebral organization: case reports and a genetic hypothesis. Brain Lang 1996;55:213-239.

2. Staudt M, Grodd W, Nieman G, Wildgruber D, Erb M, Krägeloh-Mann I Early left periventricular brain lesions induce right hemispheric organization of speech. Neurology 2001;57:122-125. 


\section{Neurology}

\section{Transient crossed aphasia during focal right-hemisphere seizure \\ A. Riecker, C. Gerloff, D. Wildgruber, et al. \\ Neurology 2004;63;1932 \\ DOI 10.1212/01.WNL.0000140690.72955.1B}

This information is current as of November 22, 2004

\section{Updated Information \& Services}

References

Citations

Subspecialty Collections

Permissions \& Licensing

Reprints including high resolution figures, can be found at: http://n.neurology.org/content/63/10/1932.full

This article cites 2 articles, 1 of which you can access for free at: http://n.neurology.org/content/63/10/1932.full\#ref-list-1

This article has been cited by 1 HighWire-hosted articles: http://n.neurology.org/content/63/10/1932.full\#\#otherarticles

This article, along with others on similar topics, appears in the following collection(s):

All Epilepsy/Seizures

http://n.neurology.org/cgi/collection/all_epilepsy_seizures Aphasia

http://n.neurology.org/cgi/collection/aphasia

Epilepsy semiology

http://n.neurology.org/cgi/collection/epilepsy_semiology

fMRI

http://n.neurology.org/cgi/collection/fmri

Information about reproducing this article in parts (figures,tables) or in its entirety can be found online at:

http://www.neurology.org/about/about_the_journal\#permissions

Information about ordering reprints can be found online:

http://n.neurology.org/subscribers/advertise

Neurology ${ }^{\circledR}$ is the official journal of the American Academy of Neurology. Published continuously since 1951, it is now a weekly with 48 issues per year. Copyright . All rights reserved. Print ISSN: 0028-3878. Online ISSN: 1526-632X.

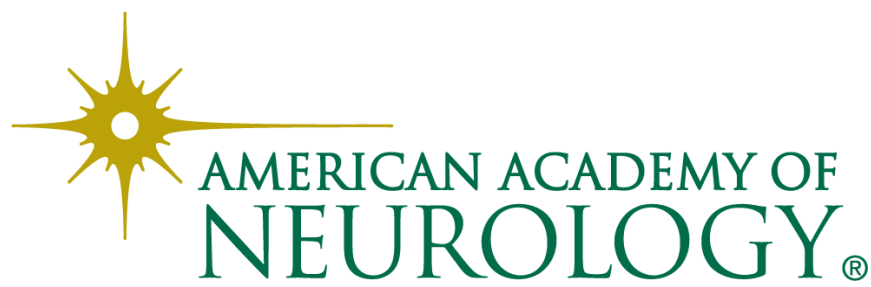

